\title{
Health Care Assessment of Health Care Delivery and Outcome- A West African Review
}

\author{
Lydia T. Cassell ${ }^{1 *}$, Ayun K. Cassell ${ }^{2}$ \\ ${ }^{1}$ Department of Public Health, Cuttington University School of Graduate and Professional Studies, Monrovia Liberia \\ ${ }^{2}$ Department of Surgery, Liberia College of Physicians and Surgeons, Monrovia Liberia
}

\author{
DOI: $10.36348 /$ SJM.2019.v04i11.001 \\ | Received: 01.11.2019| Accepted: 10.11.2019| Published: 04.11.2019 \\ *Corresponding author: Ayun K. Cassell
}

\section{Abstract}

There is currently a global effort to improve universal health coverage through the sustainable millennium development Goal. Nevertheless, much of Sub-Saharan African is still challenged by a dismal health system due to poor governance, corruption, extreme poverty and the lack of priority. The result is lack of health facility, poor health practitioner to patient ratio, with subsequent rise in maternal and child mortality. Much effort through appropriate health financing, training of health practitioner and socioeconomic development is needed to reduce the current health crisis.

Keywords: Assessment, Healthcare, Mortality.

Copyright @ 2019: This is an open-access article distributed under the terms of the Creative Commons Attribution license which permits unrestricted use, distribution, and reproduction in any medium for non-commercial use (NonCommercial, or CC-BY-NC) provided the original author and source are credited.

\section{INTRODUCTION}

Health is increasingly acknowledged as a strategic characteristic of human and economic development in Africa [1]. African nations are now increasing investment in projects and reforms to improve health outcomes and accelerate progress towards meeting the health Sustainable Millennium Development Goals (MDGs) [1]. However, in subSaharan Africa, a region characterized by political unpredictability, poor governance, natural resource wealth, and extreme poverty, human development indicators, particularly health outcomes, continue to lag in comparison to the rest of the world [2].

Africa has fewer than half the number of doctors per 1000 people than South-East Asia [3]. Almost half the world's deaths of children under five occur in Africa [4]. The dearth of doctors, nurses and other health care specialists on the African continent poses a real challenge to its healthcare system in general and deserves to be treated with the urgency and importance it merits [5]. This is further compounded by lack of health infrastructure, and especially the high incidence of Human Immunodeficiency Virus (HIV) and (Acquired Immune Deficiency Syndrome) AIDS, tuberculosis, malaria and other diseases that kill millions and specifically women and children on the continent [5]. Maternal mortality, infant morbidity and mortality rates are high; and life expectancies very low [6].
Furthermore, the World Health Organization (WHO) recently reported that about 536,000 women died in 2005 due to complications of pregnancy and childbirth, 400 mothers died for every 100,000 live births [6]. Addressing these healthcare disparities has been a key objective of initiatives like the Millennium Development Goals [7]. However, these measures have not significantly tackled the problem of underfunding in the healthcare sector as the incidence of underfunding has continued to exacerbate [4]. High economic growth is necessary but not sufficient [8]. There is an urgent need to ensure universal access to health, education and other basic services to make the growth inclusive and "leave no one behind" [8].

The review projects an assessment of the health system in West Africa highlighting the various gaps in the health system in meeting the Sustainable Millennium Development Goal.

\section{METHODOLOGY}

The English Literature was searched from 2000 to 2019 using google, google scholar and PubMed with the search term "Health care assessment" appended Africa, Liberia, Senegal, Ivory Coast, Guinea, Guinea Bissau, Togo, Benin, Nigeria, Ghana, Mali, Burkina Faso, Niger, Sierra Leone, Cameroon, Gambia, Mauritania. A total of 15 articles were selected for the study and two publications [9,10] were reviewed for population, estimated health budget, ratio of district and specialist hospital per 100,000 population, ratio of 
doctors per 1000 population, ratio of nurses per 1000 population, average life expectancy, maternal mortality, infant mortality and categorization per gross national income (GNI). The inclusion criteria included publications with data on health assessment in West African Nations. All reviews with data from ambivalent sources were excluded. These data are represented in (Table 1-3) and a qualitative analysis was presented in the main text of the results.

\section{RESULTS RETRIEVED}

Most of the Countries in West Africa (10/17) including Benin, Burkina Faso, Gambia, GuineaBissau, Guinea, Liberia, Madagascar, Mali, Niger and Sierra Leone are classified as low income countries as shown in (Table 1) with a Gross National Income (GNI) per capita of less than USD 1025.00. There are 7 countries regarded as lower middle income, Ghana, Mauritania, Nigeria, Senegal, Cameroon, Cape Verde, and Cote d' Ivoire with GNI per capita of $\$ 1,026$ to $\$ 4,035$. None of the West African nation has reached the upper middle-income status of 2019. The most populated nation in West Africa is Nigeria with an estimated population of 200,963,599. In 2016, the Nigerian health budget was estimated about $3.35 \%$ of the Gross Domestic Product (GDP). Regardless, much smaller nations like Liberia and Sierra Leone had a relatively higher percentage budget allocation at $9.62 \%$ and $16.53 \%$ of GDP respectively (Table 2). Despite Guinea Bissau having an estimated $6.09 \%$ of the GDP as health budget, it has the highest amount of hospital per 100,000 population with district hospital at 25.64/100,000 population and specialist hospital at 30.81 between 2008 and 2013. Irrespective of the estimated health budget, Liberia, Nigeria and Sierra Leone had the highest maternal mortality rate $725 / 100,000,814 / 100,000$ and 1360/100,000 live births respectively. Between 2008 and 2016, there were 0.02 Physician to 1000 population in Liberia and similar rate in Sierra Leone with an average life expectancy of 62.5 years and 53.1 years respectively (Table 3 ). However, Senegal and Gambia had the highest average life expectancy of 66.8 years and 68 years respectively.

Table-1: The Gross National Income per Capita and Categorization of West African nations into Income brackets [9]

\begin{tabular}{|l|l|}
\hline Gross National Income per Capita & West African Countries \\
\hline High income countries (GNI/capita>12,475) & None \\
\hline $\begin{array}{l}\text { Upper middle-income countries (GNI/capita } \\
\$ 4,036 \text { to } \$ 12,475)\end{array}$ & None \\
\hline $\begin{array}{l}\text { Lower-middle income countries (GNI/capita } \\
\$ 1,026 \text { to } \$ 4,035)\end{array}$ & $\begin{array}{l}\text { Cameroon, Côte d'Ivoire, Cape Verde } \\
\text { Ghana, Mauritania, Nigeria, Senegal, }\end{array}$ \\
\hline Low income countries (GNI/capita \$1,025 or less) & $\begin{array}{l}\text { Benin, Burkina Faso, Gambia, Guinea-Bissau, Guinea, Liberia, Madagascar, } \\
\text { Mali, Niger, Sierra Leone }\end{array}$ \\
\hline
\end{tabular}

GNI: Gross National Income

Table-2: The population of West African nations, the estimated health budget and hospital density [10]

\begin{tabular}{|l|l|l|l|l|}
\hline Countries & $\begin{array}{l}\text { Population } \\
(\mathbf{2 0 1 9})\end{array}$ & $\begin{array}{l}\text { Estimated Health Budget } \\
(\% \text { Of GDP) (2016) }\end{array}$ & $\begin{array}{l}\text { District Hospital per 100,000 } \\
\text { population (2008-2013) }\end{array}$ & $\begin{array}{l}\text { Specialist Hospital/100,000 } \\
\text { population (2008-2013) }\end{array}$ \\
\hline Liberia & $4,937,374$ & 9.62 & 0.35 & 0.02 \\
\hline Burkina Faso & $20,321,378$ & 6.75 & 0.25 & 0.05 \\
\hline Sierra Leone & $7,813,215$ & 16.53 & No data & No data \\
\hline Mauritania & $4,525,696$ & 4.24 & 0.69 & 0.18 \\
\hline Gambia & $2,347,706$ & 4.43 & 0.38 & 0.11 \\
\hline Mali & $19,658,031$ & 3.82 & 0.39 & 0.03 \\
\hline Nigeria & $200,963,599$ & 3.65 & No data & No data \\
\hline Benin & $11,801,151$ & 3.86 & 0.25 & 0.11 \\
\hline Guinea Bissau & $1,920,922$ & 6.09 & 25.64 & 30.81 \\
\hline Ghana & $30,417,856$ & 4.45 & 1.30 & 0.03 \\
\hline Cote d'Ivoire & $25,716,544$ & 4.40 & 1.16 & 0.10 \\
\hline Guinea & $12,771,246$ & 5.48 & 0.26 & 0.03 \\
\hline Senegal & $16,296,364$ & 5.51 & 0.16 & 0.16 \\
\hline Togo & $8,082,366$ & 6.62 & 0.51 & 0.09 \\
\hline Niger & $23,310,715$ & 6.23 & 0.43 & 0.06 \\
\hline Cameroon & $25,984,670$ & & 0.67 & 0.04 \\
\hline
\end{tabular}


Table-3: Physician density ratio, Nurse Density ratio, average life expectancy, maternal mortality and infant mortality [10]

\begin{tabular}{|l|l|l|l|l|l|}
\hline Countries & $\begin{array}{l}\text { Physician } \\
\text { Density/1000 } \\
\text { Population } \\
\mathbf{2 0 0 8 - 2 0 1 6 )}\end{array}$ & $\begin{array}{l}\text { Nurses + } \\
\text { Midwives } \\
\text { Density/1000 } \\
\text { population } \\
\mathbf{2 0 0 8 - 2 0 1 6 )}\end{array}$ & $\begin{array}{l}\text { Average Life } \\
\text { Expectancy } \\
\text { WHO (2016) }\end{array}$ & $\begin{array}{l}\text { Maternal } \\
\text { Mortality 2015 } \\
\text { per 100,000 live } \\
\text { births }\end{array}$ & $\begin{array}{l}\text { Infant Mortality } \\
\text { per 1000 live } \\
\text { births }\end{array}$ \\
\hline Liberia & 0.02 & 0.46 & 62.50 & 725 & 56 \\
\hline Burkina Faso & 0.05 & 0.55 & 63.00 & 371 & 51 \\
\hline Sierra Leone & 0.02 & 0.32 & 53.10 & 1,360 & 82 \\
\hline Mauritania & 0.13 & 0.66 & 58.50 & 602 & 53 \\
\hline Gambia & 0.11 & 1.62 & 68.00 & 706 & 41 \\
\hline Mali & 0.09 & 0.44 & 58.00 & 587 & 66 \\
\hline Nigeria & 0.37 & 1.49 & 55.20 & 814 & 65 \\
\hline Benin & 0.15 & 0.60 & 63.00 & 405 & 64 \\
\hline Guinea Bissau & 0.08 & 0.65 & 58.00 & 549 & 56 \\
\hline Ghana & 0.10 & 0.93 & 62.50 & 319 & 36 \\
\hline Cote d'Tvoire & 0.14 & 0.48 & 54.60 & 645 & 64 \\
\hline Guinea & 0.08 & 0.37 & 58.50 & 679 & 56 \\
\hline Senegal & 0.07 & 0.31 & 66.80 & 315 & 33 \\
\hline Togo & 0.06 & 0.30 & 58.00 & 368 & 49 \\
\hline Niger & 0.02 & 0.14 & 58.00 & 553 & 48 \\
\hline Cameroon & 0.08 & 0.52 & & & \\
\hline
\end{tabular}

\section{DISCUSSION}

Most West African Nations have yearned for a better and resilient health system. Most people in these regions advocate that health should be available for all rather than a privileged few. Despite the growing need and quest for a better health care system, there is still a major deficit in health care delivery $[2,3]$. The health system has been designed principally for urban elites in Africa solely neglecting the needs of women and children in rural settings. Between 2008 and 2016, there were 0.02 Physician to 1000 population in Liberia and similar rate in Sierra Leone with most of the physicians in urban settings $[9,10]$. Most Countries in West Africa have a relatively low hospital to population density with limited specialist care facilities (table 2). This poses a major barrier to assessing timely and quality health care. The prevalence of malnutrition, poor hygiene, environmental and water supply contamination, and endemic communicable diseases are still plaguing the vulnerable and socioeconomically deprived population $[2,10]$. Collaborated efforts have been made to alleviate these challenges in the health care system but corruption, lack of health prioritization, limited resource, poor resource management and underfunding of the health system have remained a hurdle to a functional and efficient health delivery system [9,10]. For the West African continent to emancipate from this hurdle, more focus should be placed on proper health financing, universal health coverage with cost efficient measures to reduce maternal mortality and child mortality.

\section{Health Financing in West Africa}

Health financing in Africa has grown rapidly in recent decades and has been driven in large part by spending on HIV/AIDS and malaria. This spending has increased from 20 percent in 2000 , to 35 percent in
2014 in Low income countries [11]. However, irrespective of the increasing health budget, Liberia, Nigeria and Sierra Leone had the highest maternal mortality rate $725 / 100,000,814 / 100,000$ and $1360 / 100,000$ live births respectively in $2015[9,10]$. This signifies that specific health proponents have not been prioritized. Corruption and poor resource management all play a significant role in poor health outcome against increasing health budgetary allocations.

The World Health Assembly resolution 58.33 from 2005 says everyone should be able to access health services and not be subject to financial hardship in doing so [6]. Most Africans live an average of 14 years less than the average for the rest of the world [3]. The lowest Life expectancy in 2016 was seen in Sierra Leone and Ivory Coast as shown in (table 3). These could be as a result of the increasing prevalence of HIV/AIDS, Tuberculosis and Malaria [11]. SubSaharan Africa has about 11 percent of the world's people, but it carries 24 percent of the global disease burden in human and financial costs [4]. Most of the Countries in the West African region (10/17) including Benin, Burkina Faso, Gambia, Guinea-Bissau, Guinea, Liberia, Madagascar, Mali, Niger and Sierra Leone are classified as low income countries as shown in (Table 1) with a Gross National Income (GNI) per capita of less than USD 1025.00. Reports from the West Africa Economic Outlook 2018 published data which was reposted by the African Development Bank Group stipulated that there is much inequality and underemployment causing poverty, with 43 percent of the population below the international $\$ 1.90$ per day poverty line in 2013 (the most recent estimate) [9]. Addressing these healthcare disparities has been a key objective of initiatives like the Millennium Development Goals [6]. In 2001, African Union heads 
of state pledged to allocate at least $15 \%$ of annual expenditure to health under the Abuja Declaration [3].

Indeed, by focusing too much attention on reaching certain expenditure levels, policy makers may actually lose sight of other challenges, such as improving the way existing resources are allocated and used in the health sector [3]. The adoption of the Addis Ababa Action Agenda on Financing for Development and of the new Sustainable Development Goals (SDGs) in the second half of 2015 has been accompanied by a growing recognition of the need to explore the nature of the resources available and the use to which they are put, rather than focusing solely on the volume of resources required to make progress toward universal health coverage (UHC) [3].

In the 2010s, there was a more explicit push for UHC, to the point of being officially included as an official target of the Sustainable Development Goals for 2016-2030 [7]. The rise on the international scene of advocacy for UHC was thus accompanied by the promotion of new health financing policies (e.g., health insurance, user fee exemption, and results-based financing), which donors presented as relevant instruments for achieving UHC [7].

Despite national and international efforts, health interventions are not adequately meeting the health needs of the people, especially those living in poor and marginalized communities [11].

\section{Disease Morbidity and Mortality in West Africa}

In 2015, approximately 303,000 women died from complications of pregnancy and childbirth [12]. Western Africa has among the highest maternal mortality rates in the world with a maternal mortality ratio (MMR; maternal deaths per 100,000 live births) of 679 in 2015 [13]. In 2015, Countries like Sierra Leone, Liberia, Nigeria, Ivory Coast, Guinea, Gambia, Mauritania and Guinea Bissau presented with some of the highest maternal mortality compared to the Europe and America. These statistics confirm that Millennium Development Goal 5 (reducing the maternal mortality ratio by three-quarters between 1990 and 2015) was not universally achieved, particularly in sub-Saharan Africa [12]. Most deaths $(99 \%)$ occurred in low and middleincome countries, with sub-Saharan Africa accounting for nearly two-thirds (66\%) [12]. The causes of death as provided by health providers and facility records include birth asphyxia (suffocation during birth), 40\%; prematurity and low birth weight, 25\%; infections, $20 \%$; congenital defects, $10 \%$, and acute surgical conditions, $3 \%$. Other adverse findings include unavailability of basic supplies and equipment, staff shortages and low morale, bad roads and long distances between referral points, continued use of traditional birth attendants (who are still popular and highly regarded) and preference of mothers to deliver in health facilities [14]. Poverty fuels maternal mortality, experts say, which explains why death rates are higher in poor countries than in rich ones [15]. Maternal mortality ratio declines sharply at high levels of GDP per capita, though with some exceptions [8]. Despite progress in some countries, many women and babies still die during childbirth in Africa [15].

\section{CONCLUSION}

Many nations in West Africa are yet to meet the targets set in the Millennium Development Goal. The health systems in these regions are not only challenged by poor financing but also political instability, civil unrest and lack of prioritization. In other to achieve a functioning health system, integrated approaches which will include improvement in socioeconomic status, adequate health system financing and proper health system management are required.

\section{ACKNOWLEDGEMENT}

\section{We acknowledge Funmilayo Olasupo for her contribution to this work.}

\section{Conflict of Interest}

The authors declare no conflict of interest towards this publication.

\section{Funding}

No external funding available.

\section{Author Contributions}

Conceptual design: LC, AC. Analysis, drafting and critical revision of the article: LC, AC. Final approval of the article: LC, AC.

\section{REFERENCES}

1. World Health Organization. State of health financing in the African Region. https://apps.who.int/iris/bitstream/handle/10665/10 1282/9789290232131.

2. Braa J, Kossi E, Mbondji P, Sahay S. Situation Assessment of Health Information Systems in the ECOWAS Region - West Africa. (2012).

3. World Health Organization. Public financing for health in Africa: from Abuja to the SDGs. World Health Organization; 2016.

4. International Finance Corporation. The Business of Health in Africa: Partnering with the Private Sector to Improve People's Lives. Washington (District of Columbia): International Finance Corporation. 2007.

5. Molefi M. An Assessment of eHealth Projects and Initiatives in Africa. World Health Organization: Geneva, Switzerland. 2010

6. Adindu A. Assessing and Assuring Quality of Health Care in Africa. African Journal of Medical Sciences 2010, vol. 3, number 1, pp. 31 -36,

7. Reuter KE, Geysimonyan A, Molina G, Reuter PR. Healthcare in Equatorial Guinea, West Africa: obstacles and barriers to care. The Pan African medical journal. 2014;19. 
8. Transform: African Business and investment forum http://repository.uneca.org/handle/10855/24288

9. GNI per capita, Atlas method (current US\$) https://data.worldbank.org/indicator/NY.GNP.PCA P.Cd

10. Atlas of the African Health Statistics 2019 http://www.aho.afro.who.int/en/atlas/atlas-africanhealth-statistics-2019

11. West Africa Economic Outlook 2018 https://www.afdb.org/fileadmin/uploads/afdb/Docu ments/Publications/2018AEO/AfricanEconomic_O utlook_2018_West-Africa.pdf

12. Merdad L, Ali MM. Timing of maternal death: Levels, trends, and ecological correlates using sibling data from 34 sub-Saharan African countries. PLoS ONE 2018. 13(1): e0189416.

13. Gunawardena N, Bishwajit G, Yaya S. FacilityBased maternal Death in western africa: a Systematic Review. Frontiers in public health. 2018 Feb 26;6:48.

14. Grieco M, Turner J. Maternal Mortality: Africa's Burden, Tookit on Gender, Transport and Maternal Mortality. World Bank. 2005.

15. Improving maternal health in Africa https://www.un.org/africarenewal/magazine/decem ber-2014/improving-maternal-health-africa 